\title{
Sustainable Development Goals (SDGs) Perspective in Regional Development Planning and Implementation
}

\author{
(The Case of Bandung Regency, West Java, Indonesia) \\ Muhamad Nur Afandi*, Endah Tri Anomsari, Alikha Novira \\ Politeknik STIA LAN Bandung \\ Bandung, Indonesia \\ *m.nurafandi@poltek.stialanbandung.ac.id
}

\begin{abstract}
Sustainable Development Goals (SDGs) address the most pressing global development issues and many countries, including Indonesia, integrate the goals into their national and local development. This study uses a qualitative approach in exploring the integration of SDGs into regional development planning and implementation in Bandung Regency, West Java, Indonesia. This study reveals there is an integration of SDGs into Bandung Regency's 2016-2021 regional planning. The local government has the autonomy to implement 16 out of 17 goals, except SDG 14 (Life below Water), which remains under the central government's authority. Bandung Regency planned to implement 220 indicators in its 2016-2021 regional development planning, in which 140 of them $(69 \%)$ has been achieved by 2019 . The greatest achievement by Bandung Regency is SDG 7 (Affordable and Clean Energy) and SDG 13 (Climate Change), while the opposite side is SDG 4 (Quality Education) which still falls behind. The study then explores the challenges in integrating and implementing SDGs in local development, including poor cross-sectoral coordination, the lack of knowledge about doing SDGs, and confounding local indicators and data collection.
\end{abstract}

Keywords - sustainable development goals, regional planning, development implementation, local development

\section{INTRODUCTION}

Since its declaration on 25th September 2015, Sustainable Development Goals (SDGs) as a global development agenda and commitment are integrated into a national development in 170 countries and territories. Since then, SDGs brings significant implications to post-2015 national development planning in developed and developing countries [1]. Indonesia also puts 17 goals and 169 targets of SDGs into its national planning. The integration is based on the country's standing and support to SDGs as the global goals which address the most pressing development issues. By integrating SDGs with its development agenda, the Indonesian government aims to bring about development that results in national communities that are independent, developed, fair, and prosper as posited in its Long-Term National Development Planning (known as RPJP).
In practice, the implementation of SDGs requires the role of local governments, especially in a country like Indonesia which applies a decentralization system. In this system, local governments possess the authority to undertake development according to their aspirations and needs. However, integrating SDGs into national and local planning is not an easy task. SDGs represent a broad, integrated, and complex development agenda which are challenging to implement [2]. The success relies heavily on the implementation by countries, which also have their national agenda besides the SDGs. The local government then plays an important role as an implementing partner of SDGs to ensure that the global and national targets can be set, implemented, and monitored locally [3]. Achievement of SDG targets is also determined by development achievement at the local level [4]. Further, Oostenhorf [4] argues that achieving SDGs targets need an effective integration between SDGs and cross-sectoral collaboration in all levels of development.

According to Sustainable Development Report 2020, the SDG index of Indonesia ranks 101 out of 166 countries. The major challenges in Indonesia include the issues of hunger, health and well-being, clean water and sanitation, industry innovation and infrastructure, life on land, and global partnership [5]. Facing the challenges, Bandung Regency, one of the regencies in West Java, integrated the goals into its medium-term development planning and implementation in 2015-2019 and 2020-2024. In the process, there are challenges in integrating the goals into regional development, which then become the focal point in this study. This paper is a qualitative exploration of how the Bandung Regency government integrates SDGs into its local development planning and implementation in the 2016-2021 term, including the challenges it faced during the process. By analyzing the challenges in the previous Bandung Regency's medium-term planning, this paper brings an analytical contribution that can be a lesson for future regional planning in the regency. 


\section{THEORETICAL FRAMEWORK}

Development has a political and highly debated concept and definition, but it is frequently associated with progress. Development is a term commonly used to refer to an intervention undertaken to manage changes in a way that suitable for the intended goals. Peet and Hartwick [6] defines development in a broader sense, as a better life for everyone. As a contested concept, development is therefore presented in a variety of theories or paradigms. Development is often viewed through modernization lenses, in which development is seen primarily as a transformation from traditional to modern society. The five stages of growth by Rostow [7] falls into the modernization theory. According to Rostow [7], society makes a progress from traditional to modern society through five development stages, namely traditional society, pre-condition to take off, take off, drive to maturity, and high mass consumption. Critiques to modernization theory include its premise that development is linear in progress and its strong emphasis on economic when development itself is more complicated and multi-dimensions.

On a different spectrum from modernization is the dependency theory, which stems from the 'dependecia' concept that emerged among Latin American thinkers such as Prebisch, Furtado, Sunkel, Cardoso, Faletto, and Gunder Frank. Dependency theory emphasizes the relationships of a nation with the others, in which nation underdevelopment is closely linked to how other countries expand their economies. Countries in the world are divided into two categories, core countries which hold the domination in the global political economy, and periphery countries which are exploited and dependent on the core ones. There is also world system thinking proposed by Wallerstein, which argues that the world system consists of a core, semi-periphery, and periphery countries.

Amidst the debate in development conceptualization, there is growing attention to the environmental aspect. The rapid progress the world experiences since the Industrial Revolution in the 18th century has brought significant impacts to the environment, which brings the realization that development must be conducted with the future generations in the mindset. In 1990, held The World Conference on Environment and Development (WCED), which marks the decline of modernization as the industrial development model [8]. Two years later, held The United Nations Conference on Environment and Development (UNCED) or "The Earth Summit" as a global initiative to make development more sustainable. Essentially, sustainable development is "...development that meets the needs of the present without compromising the ability of future generations to meet their own needs" (Brundtland Commission in 1987). Similarly, Engel defines sustainability as all human activities that continuously meet the needs of communities across the globe [9].

Sustainable Development Goals (SDGs) stems from the idea of maintaining the balance between making progress and meeting the needs with thinking about future generations. With a pledge of "No One Left Behind", SDGs formulate more inclusive 17 goals which address most pressing global issues and include 5P, those are People, Planet, Prosperity, Peace, and Partnership. The 17 SGDs are, in order, (1) No Poverty, (2) Zero Hunger, (3) Good Health and Well-Being, (4) Quality Education, (5) Gender Equality, (6) Clean Water and Sanitation, (7) Affordable and Clean Energy, (8) Decent Work and Economic Growth, (9) Industry, Innovation, and Infrastructure, (10) Reduced Inequalities, (11) Sustainable Cities and Communities, (12) Responsible Consumption and Production, (13) Climate Action, (14) Life below Water, (15) Life on Land, (16) Peace, Justice and Strong Institutions, and (17) Partnerships for the Goals.

SDG's 17 goals have a total of 169 targets, which were formulated through a set of a more deliberative and inclusive process than its predecessor, the Millennium Development Goals (MDGs). However, SDGs still receive critiques. For instance, Battersby [10] asserts the lack of attention to food security issues in SDGs as it does not pay attention to the changing location and characteristics of food and nutrition security, particularly in African countries. The issue is included in Goal 2 (Zero Hunger), but it shall be "central, rather than peripheral to the SDG agenda" [10]. The implementation of SDGs is deemed even more challenging as it requires integration with development planning at all levels of development practices [4]. Despite the critiques, SDGs remain to be agenda which is adopted in 178 countries and territories Indonesia issues policies to accommodate SDGs in its development initiatives, such as through Presidential Regulation No. 59 the Year 2017 about the Implementation of Sustainable Development Achievement. This regulation becomes the legal standing in integrating SDGs into national and local planning in the country.

Theoretically, it is possible to translate SDGs into sustainability initiatives with local impact, as analyzed by Raub and Martin-Rios [11]. Using hospitality firms as the context of analysis, Raub and Martin-Rios [11] reveal the importance of participation in establishing partnerships with stakeholders. They also assert an ambitious roadmap to identify local actions committed to economic, social, and environmental sustainability. The steps in the roadmap includes analyzing the contribution of the sector to SDGs, identifying all stakeholders, listing the catalysts and obstacles faced by each stakeholder, determining the implementation probability index for each sustainable goal, shortlisting and selecting high impact goals, multiplying organizational initiatives, and building network and collaboration. Empirically, how Bandung Regency integrated SDGs into its 2015-2019 planning and then implemented the programs related to the goals is then explored in this study.

\section{RESEARCH METHODS}

This study is conducted using a qualitative approach to local development planning and subsequent implementation in SDGs perspective. The research uses a qualitative method, while data collection is conducted through in-depth interviews, 
observation, literature analysis, and focus group discussion with the government bodies in Bandung Regency, including the Regional Secretariat, Agency for Regional Development Planning, and Agency for Village Community Development. Following data collection, the research proceeds to an analysis of the integration process of SDGs into Bandung Regency local planning and implementation and explore the challenges faced by the regency in the process.

\section{DATA AND ANALYSIS}

Integrating SDGs into development practices is a challenging task, even more so in local development. Despite the challenge, SDGs have become goals to achieve by local government in Indonesia since the issuing of Presidential Decree No. 59 of 2017 about SDGs Implementation. Following the mandate by the central government, Bandung Regency integrates 16 of 17 SDGs into its development planning and subsequently, development practices. One sustainable goal remains under the central government authority, which is SDG 14 (Life Below Water), while the remaining 16 SDGs are implemented by local governments across the nation. This is possible to be undertaken in Indonesia in which the administration uses a decentralization system, while its development process encourages a bottom-up approach.

In achieving the goals, targets, and indicators stipulated in SDGs, the government of Bandung Regency integrates SDGs into its development planning. This can be seen through four agendas, which are: (1) medium-term development planning in the regency, particularly the 2016-2021 period, clearly refers to SDGs as strategic issues that need to be addressed; (2) the regency vision in the respective period uses environmental approach; (3) the five missions of the regency medium-term development are closely linked to the issues addressed in SDGs; (4) the creation of medium-term development target, strategies, policies, and programs consistently show a relationship to SDGs. These documents are created through a technocratic and political approach, which results in the planning accommodating not only SDGs but also local political, economic, and social interests. In total, there are 25 medium-term development programs, with all can be linked to SDGs, as shown in Table 1.

TABLE I. LINK OF DEVELOPMENT PROGRAMS AND SDGS

\begin{tabular}{|l|l|l|}
\hline No. & \multicolumn{1}{|c|}{$\begin{array}{c}\text { Medium-Term Development } \\
\text { Programmes (2016-2021) }\end{array}$} & Related SDGs \\
\hline 1 & $\begin{array}{l}\text { Increasing accessibility to formal and } \\
\text { nonformal education }\end{array}$ & Quality Education \\
\hline 2 & $\begin{array}{l}\text { Improving the quality of formal and } \\
\text { nonformal education }\end{array}$ & \\
\hline 3 & Improving community health services & $\begin{array}{l}\text { Good Health \& } \\
\text { Wellbeing }\end{array}$ \\
\hline 4 & Improving community quality of life & $\begin{array}{l}\text { Sustainable Cities } \\
\text { and Communities } \\
\text { Clean Water \& } \\
\text { service }\end{array}$ \\
\hline 6 & Optimizing irrigation system & Sanitation \\
\hline 8 & Improving the quality of a residential area & \\
\hline
\end{tabular}

Table 1. Cont.

\begin{tabular}{|c|c|c|}
\hline 9 & $\begin{array}{l}\text { Optimizing women and child protection and } \\
\text { gender mainstreaming }\end{array}$ & Gender Equality \\
\hline 10 & Social protection program & \multirow{2}{*}{$\begin{array}{l}\text { Reduced } \\
\text { Inequalities }\end{array}$} \\
\hline 11 & $\begin{array}{l}\text { Village development and community } \\
\text { development }\end{array}$ & \\
\hline 12 & $\begin{array}{l}\text { Poverty reduction and social welfare } \\
\text { program }\end{array}$ & No Poverty \\
\hline 13 & c farming & \multirow{3}{*}{$\begin{array}{l}\text { Decent Work \& } \\
\text { Economic Growth }\end{array}$} \\
\hline 14 & Competitive service and trade development & \\
\hline 15 & $\begin{array}{l}\text { Cooperative, small and medium business, } \\
\text { and creative economy development }\end{array}$ & \\
\hline 16 & Local culture and tourism development & \multirow{2}{*}{$\begin{array}{l}\text { Industry, } \\
\text { Innovation, \& } \\
\text { Infrastructure }\end{array}$} \\
\hline 17 & teffectiv & \\
\hline 18 & Imprc & Zero Hunger \\
\hline 19 & Improving disaster management standard & \multirow{3}{*}{$\begin{array}{l}\text { Climate Action } \\
\text { Affordable } \quad \& \\
\text { Clean Energy }\end{array}$} \\
\hline 20 & Flood prevention & \\
\hline 21 & $\begin{array}{l}\text { Managing pollution and environmental } \\
\text { damage }\end{array}$ & \\
\hline 22 & onservation & $\begin{array}{l}\text { Responsible } \\
\text { Consumption \& } \\
\text { Production } \\
\text { Life On Land }\end{array}$ \\
\hline 23 & Increasing bureaucracy professionalism & \multirow{3}{*}{$\begin{array}{l}\text { Peace, Justice, and } \\
\text { Strong Institutions }\end{array}$} \\
\hline 24 & $\begin{array}{llll}\text { Improving local asset } & \text { and } & \text { financial } \\
\text { accountability }\end{array}$ & \\
\hline 25 & Improving regional stability and security & \\
\hline
\end{tabular}

According to Table 1, it can be seen medium-term development programs in Bandung Regency have been linked to SDGs. The SDG 17 (Partnerships for the Goals) is not linked directly with a particular program, but it is a part of the development process as Bandung Regency holds partnerships with other development actors at local and national levels. The link between those programs and SDGs leads to a conclusion that in terms of planning, SDGs have been integrated into local development planning. The next question is whether the implementation has shown an achievement of SDGs.

The government of Bandung Regency has implemented 16 out of 17 SDGs under their authority, with a total of 202 chosen SDG indicators. An evaluation of SDGs practices until 2020 is shown in Table 2.

TABLE II. EVALUATION OF SDGS IN BANDUNG REGENCY

\begin{tabular}{|c|c|c|c|c|c|}
\hline SDG & 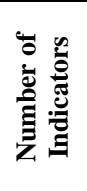 & 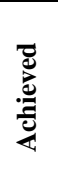 & 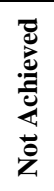 & 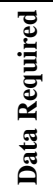 & $\overleftrightarrow{\mathbf{z}}$ \\
\hline No poverty & 23 & 18 & 5 & - & - \\
\hline Zero hunger & 11 & 8 & 1 & 2 & - \\
\hline Good health and wellbeing & 32 & 21 & 6 & 3 & 2 \\
\hline Quality education & 12 & 3 & 7 & 2 & - \\
\hline Gender equality & 14 & 9 & 5 & - & - \\
\hline Clean water and sanitation & 17 & 10 & 5 & 2 & - \\
\hline Affordable and clean energy & 1 & 1 & - & - & - \\
\hline Decent work and economic growth & 18 & 11 & 2 & 4 & 1 \\
\hline
\end{tabular}


Table 2. Cont.

\begin{tabular}{|l|l|l|l|l|l|}
\hline $\begin{array}{l}\text { Industry, innovation, \& } \\
\text { infrastructure }\end{array}$ & 11 & 10 & - & 1 & - \\
\hline Reduced inequalities & 7 & 5 & 1 & - & 1 \\
\hline Sustainable cities and communities & 10 & 9 & 1 & - & - \\
\hline $\begin{array}{l}\text { Responsible consumption and } \\
\text { production }\end{array}$ & 5 & 3 & 2 & - & - \\
\hline Climate action & 2 & 2 & - & - & - \\
\hline Life below water and strong & 0 & - & - & - & - \\
\hline Life on land justice, a & 4 & 2 & 2 & - & - \\
\hline $\begin{array}{l}\text { Peace, } \\
\text { institutions }\end{array}$ & 15 & 14 & 6 & - & - \\
\hline Partnerships for the goal & $\mathbf{2 0 2}$ & $\mathbf{1 4 0}$ & $\mathbf{4 4}$ & $\mathbf{1 4}$ & $\mathbf{4}$ \\
\hline Total
\end{tabular}

Source: Agency for Regional Development Planning of Bandung Regency (2020).

According to the evaluation in Table 2, it is known that Bandung Regency has achieved 69\% (140 indicators), while 22\% (44 indicators) are not yet achieved in 2016-2020. Around 7\% (14 indicators) requires data collection, while the information about the remaining 2\% (4 indicators) are unknown. The biggest achievement by Bandung Regency is SDG 7 (Affordable and Clean Energy) and SDG 13 (Climate Change), while the opposite side is SDG 4 (Quality Education) and SDG 12 (Responsible Consumption and Production) which still fall behind. This evaluation shows that SGD has been implemented at a local level, but several challenges present in the region.

1) Poor cross-sectoral coordination between government agencies. SDGs are integrated appropriately into medium-term development planning, but the success of implementation is determined by more factors. Medium-term planning needs to be cascaded into an annual program(s), which are then undertaken by the sectoral government agencies in Bandung Regency. Each medium-term program may be implemented by different government bodies. Consequently, cross-sectoral coordination between government agencies becomes a contributing factor in SDGs achievement. In this respect, government bodies in Bandung Regency still require evaluation and improvement.

2) Lack of technical knowledge about doing SDGs. Integrating and implementing SDGs, which are created and aimed at a global level, is a challenging task for local government. Even though the concept of SDGs is well-known among government officials, how to integrate and implement them on the local level is difficult, even more so when the local technical guide and policies about how to do SDGs are inadequate.

3) Confounding local indicators and data collection. Every goal in SDGs comes with its respective target and indicators, but due to the limited resource faced by the local government, data about those indicators are incomplete or unavailable. Indicators become more confounding as the success of development in the regency is measured not only from the perspective of SDGs but also from the lenses of local politics and agendas. This confusing situation happens at the local level, which constrains local government agencies from fully implementing SDGs.

Drawing from the challenges that appear in the region in integrating and implementing SDGs at local development in Bandung Regency in 2016-2021, there are two suggestions for future actions. Firstly, the local government must formulate local indicators and set priorities concerning SDGs. Aiming to achieve 202 SDGs indicators at the same time, while still responsible for doing other local development agendas is challenging, particularly when the respective local government has limited resources. The local government needs to set priorities for every medium-term planning and implementing the programs accordingly until 2030. Secondly, the process of integrating SDGs into local development at local level is tricky. Further research is necessary to put the integration process into a straightforward model that can be used for future reference in planning and implementing SDGs at the local level.

\section{CONCLUSION}

SDGs are relevant to the development issues in Indonesia, which leads to the country's government to implement development initiatives to achieve them. The role of local government is important as the country applies a decentralization system. Bandung Regency has held the mandate, as shown in its 2016-2021 medium-term development planning. The medium development plans have integrated SDGs, in which all programs can be linked with SDGs. However, from the SDGs perspective, the implementation of those programs is suboptimal as the regency face constraints such as poor cross-sectoral coordination, confounding data, and lack of technical knowledge about how to implement SDGs.

\section{REFERENCES}

[1] C. Allen, G. Metternicht, \& T. Wiedmann, National pathways to the Sustainable Development Goals (SDGs): a comparative review of scenario modelling tools, "Environmental Science \& Policy", 66, 199. 207. 2016.

[2] C. Allen, G. Metternicht, \& T. Wiedmann, An iterative framework for national scenario modelling for the Sustainable Development "Goals (SDGs)', Sustainable Development", 2017.

[3] L. Slack, The post-2015 global agenda - a role for local government, "Commonwealth Journal of Local Governance", 16/17, 4483. 2015.

[4] P.D. Oosterhof, Localizing the SDGs to Accelerate Implementation of the 2030 Agenda. "Asian Development Bank", 33. 2018

[5] J. Sachs, G. Schmidt-Traub, C. Kroll, G. Lafortune, G. Fuller, \& F. Woelm, "The Sustainable Development Goals and Covid-19. Sustainable Development Report 2020". Cambridge University Press. 2020.

[6] R. Peet \& E.R. Hartwick, "Theories of development: contentions, arguments, alternatives". New York: The Guilford Press. 2009.

[7] W.W. Rostow, The Stages of Economic Growth. "The Economic History Review", 12(1), 1-16. 1959.

[8] P. Woodhouse \& A. Chimhowu, "Development studies, nature and natural resources: changing narratives and discursive practices", in Kothari (Eds) A Radical History of Development Studies: Individuals, Institutions, and Ideologies, London: Zed Books. 2005.

[9] H. Bossel, Indicators for Sustainable Development: Theory, Method, Applications, Winnipeg: The International Insittute for Sustainable Development (IISD). 1999. 
[10] J. Battersby, MDGs to SDGs - new goals, same gaps: the continued absence of urban food security in the post-2015 global development agenda, “African Geographical Review", 36(1), 115-129, 2016.
[11] S.P. Raub \& C. Martin-Rios, "Think sustainable, act local" - a stakeholder-filter-model for translating SDGs into sustainability initiatives with local impact, "International Journal of Contemporary Hospitality Management”, 31(6), 2428-2447. 2019. 